\title{
The Ghost of New Zealand's Terrorism Past and Present
}

\author{
Author/s: John Battersby
}

To cite this article: Battersby, J. (2019). The Ghost of New Zealand's Terrorism Past and

Present. National Security Journal, 1(1), 35-47. doi:10.36878/nsj201901.35

To link to this article: https://doi.org/10.36878/NSJ201901.35

View CrossRef data: https://search.crossref.org/?q=10.36878\%2FNSJ201901.35\# 


\title{
THE GHOST OF NEW ZEALAND'S TERRORISM PAST AND PRESENT
}

\begin{abstract}
John Battersby ${ }^{1}$
The attack on two Christchurch Mosques in March 2019 was met with shock by New Zealanders and those from many other countries. There were clear assumptions expressed in the media, by commentators, politicians and even a few supposed 'experts' that this was a new experience for New Zealand. Overseas expertise was instantly sought to deal with a problem apparently not encountered before. This article addresses the assumption of the non-existence of terrorism in New Zealand by outlining its impact here over the past 50 years, and contends that local experience should be given strong consideration in approaching current and future terrorist threats. While the scale of the Christchurch attack was unprecedented, lone actors driven by extremist ideologies to engage in violence to send a political message to New Zealanders, is nothing new. New Zealand would not have been caught so unprepared if it had paid more attention to key events in the recent past, and taken steps to mitigate terrorist risks that could have been foreseen.
\end{abstract}

Keywords: New Zealand, Terrorism, Left-Wing Extremism, Right-Wing Extremism, Christchurch, Suppression of Terrorism Act

On 15 March 2019, New Zealand experienced its first 21st century act of terrorism on its own soil in which lives were lost. A 23 year-old Australian male armed with semi-automatic weapons attacked two Christchurch mosques, one after the other. He killed 51 people and left several others injured. The attack caught New Zealand unawares, its suddenness complemented by its severity - unprecedented in New Zealand history. Brenton Tarrant has become the first person to be charged with committing a terrorist act in New Zealand. However, the Christchurch atrocity was not the first terrorist attack in New Zealand's contemporary history, nor was Tarrant our first autonomous actor. It

1 Dr John Battersby is a Teaching Fellow at the Centre for Defence and Security Studies at Massey University, Wellington, and Managing Editor of National Security Journal. Contact by email j.m.battersby@massey.ac.nz 
is not the first time lives have been lost, nor the first time New Zealand has experienced a completely unexpected act, and been left wondering why and how it happened.

This paper therefore lays out New Zealand's history of terrorism - of violence or threats perpetrated in an attempt to influence the social and political environment. It is a history New Zealanders have preferred to ignore, because in part they have been prepared to tolerate and forgive terrorism. New Zealand has not previously prosecuted any perpetrator for committing a 'terrorist act', allowing terrorism an invisibility in law, leading to a fading collective memory of it. If New Zealanders were caught unawares on $15 \mathrm{March}$ 2019 , it was at least partly due to a tendency to block out the terrorism from their past, and then pretend they had no current problem because they had no previous one.

\section{The beginnings of modern terrorism in New Zealand}

The decade of the 1970s saw a significant surge in terrorism internationally comprising mainly bombings, aircraft hijackings and the taking of hostages. ${ }^{1}$ This terrorism aimed at displays of violence rather than killing large numbers of people. While people were killed, human casualties were generally low and sometimes avoided altogether. ${ }^{2}$ Amid this context, the involvement of the US, along with its ANZUS allies, in the Vietnam War, prompted widespread public protest in all three countries, eventually culminating in incidents of deliberate violence. In 1969 four men, despite a clumsy set of preparations, succeeded in detonating a gelignite bomb at the Waitangi Flagstaff. Their actions were motivated by the perception that peaceful protest against Vietnam was getting them nowhere so they "had to bring the war home."

Contemporary activist Tim Shadbolt described what followed as "one of the worst outbreaks of bombing that this country has seen." Over a dozen bombings occurred in 1970 alone targeting mainly military bases and government buildings. The bombings tapered off afterwards, but continued until New Zealand's decision to withdraw from the war. ${ }^{4}$ Only a few perpetrators were caught, and they were charged and convicted for arson. John Bower, convicted of bombing an RNZAF depot in Auckland in 1970, gave a press interview 40 years later. He explained "My rationale, they're dropping bombs in Vietnam, you can have one here yourself..." This was similar to the justification Shadbolt gave to the bombings at the time, that it was a reaction to protests being ignored, a need to increase pressure on an apathetic population and a non-responsive government that prompted them. Shadbolt claimed opposition to the bombing, but he was equivocal:

No, I don't agree with bombing. But if I did I'd bomb and bomb hard.

Bomb every troop train, every munitions cargo, and every supply boat that left for Vietnam.

I believe that what you have to do is blow people's minds. This is a political war more than a military one. ${ }^{6}$ 
Shadbolt was not the only Left-Wing apologist distancing themselves from, but ultimately justifying the violent actions of those who did them. The theme of 'bringing the war home' as a driver for Left-Wing violence, has also been noted as a prevailing influence for the emergence of the Right-Wing terrorist movements in the US, driven predominantly by those returning from the war who also considered their government was ignoring them.?

Amid an international upsurge in aircraft hijackings during the 1970s, hijack threats were made against Air New Zealand flights destined for French Polynesia in response to French nuclear testing in the early 1970s. Concern was sufficient that guards were placed on Air New Zealand flights to French territories in the early 1970s. ${ }^{8}$ There were occasional bomb threats associated with the nuclear testing issue throughout the 1970s.

The abortion debate in the early 1970s led to animated protest from both pro and anti-abortion groups, which saw a number of arsons targeting buildings associated with the pro-abortion movement. ${ }^{9}$ The abortion debate rumbled on for years with protest occasionally straying into acts of destruction. Even as late as 2000, an anti-abortion activist was convicted of attempted arson after disabling the sprinkler system in Lynhurst Hospital in Christchurch, and then tunnelling underneath to set the building on fire. The sentencing judge was not convinced by the perpetrator's claim that he did not intend to hurt anyone! ${ }^{10}$

The first act of international terrorism in New Zealand occurred in October 1975 when three adherents of Ananda Marga, a religious sect of Hindu origin, broke into a quarry intending to steal gelignite to bomb the Indian High Commission in Wellington. This was in response to the banning of Ananda Marga in India, and incarceration of its leader on suspicion of murder. ${ }^{11}$ While the plot was discovered by chance, the New Zealand Police quickly realised that a marked change in behaviour had taken place by a small cabal, apparently masking their activities from their own wider group, operating on both sides of the Tasman. ${ }^{12}$ Subsequent activity in Australia ultimately culminated in the bombing of the Sydney Hilton Hotel in 1978, killing three people.

However, New Zealand had no terrorism legislation in 1975, those caught then were charged with attempted arson. The New Zealand Police Terrorist Intelligence Unit (PTIU) monitored Ananda Marga for some years afterwards, but this suddenly ceased in 1979..$^{13}$ A large file of accumulated information "was later destroyed" containing "much information that was not based on fact". ${ }^{14}$ In the aftermath of the 1975 incident NZ Police continued their monitoring of Ananda Marga, but perhaps started to see threats where there weren't any - they then destroyed valuable evidence of how the apparent 'phantom' information had come about.

In 1976 two men were killed in Auckland when the bomb they were making exploded prematurely. The men were "fringe members" of the Hare Krishna movement and had 
planned to bomb a local meat works. ${ }^{15}$ One of them was thought to have been involved in the detonation of a device about 18 months previously. The two had been working in a garden shed, which was completely destroyed in the explosion, and their remains reportedly scattered some distance down the road. ${ }^{16}$

During the period April to September 1981 the South African national rugby team 'the Springboks' were on tour in New Zealand. The protest it evoked is well documented. Less well known is that five bombs exploded, four undetonated improvised explosive devices were located, and multiple bomb-threats were made against various locations. Death threats were recorded against rugby union officials, rugby players and police officers. Protest leaders discussed the use of bomb hoaxes and the placement of realistic looking devices to divert police resources from their protest activities. Violent action was contemplated by those on both sides of the tour issue - two men were arrested on separate occasions, intending to take loaded firearms to rugby games to shoot protesters. ${ }^{17}$

Near the end of the year a mentally ill lone actor was able to locate himself near the route taken by the entourage of Queen Elizabeth II as she visited Dunedin - and he fired a shot. He missed, the incident was covered-up by police - most New Zealanders would remain oblivious for almost 40 years about how close the Head of Commonwealth had come to being shot in New Zealand. ${ }^{18}$

In 1982 Neil Roberts walked into the foyer of Wairere House in Wanganui - the building purpose-built to hold the new computerised national police record system. He placed a back-pack on the floor, bent down and connected a gelignite bomb he had constructed to a battery and blew himself up. Roberts was an anarchist and follower of the punk rock phenomenon. He was not shy about expressing his opposition to the computerisation of police records, his determination not to live beyond the age of 23 and his intent to take either Parliament or the computer centre down with him when he died. His close friends knew of his intentions but never warned anyone, and despite very little knowledge of explosives he was able to plan and execute New Zealand's first suicide bombing. Nicky Hager argues Roberts was right to be alarmed about "authoritarian government and digital technology." However, Hager was 'reluctant' to label Roberts a suicide bomber:

Suicide bomber has completely different connotations these days. It means killing other people. This is much more in the tradition of those monks that burnt themselves in front of parliament buildings. That is where you are hurting yourself but it's not a suicide bomber it's a political act, like starving yourself to death in a hunger strike. ${ }^{19}$

Like Shadbolt, Hager seems to be denying that an act of political violence is terrorism because it is an act of political violence and the nobility of the cause made it alright. 
Roberts detonated his bomb late at night, probably to avoid casualties other than himself, but the Lynhurst Hospital arsonist and the Rainbow Warrior bombers all claimed after the fact, that they did not intend to harm anyone either.

In 1984 a suitcase was placed inside the Wellington Trades Hall. When it was eventually moved by the care-taker, the bomb inside the suitcase exploded and killed him. The Trades Hall was a well-known hub of union and Left-Wing political activity, leaving it highly likely to have been a politically inspired attack by a perpetrator with Right-Wing leanings. The death toll of one could have been much higher, it was a well-used building located on an arterial route through the city. The case remains open with very recent developments in the case leading to the naming of a suspect. ${ }^{20}$

In July 1985 New Zealand's most labelled act of terrorism occurred when French secret service agents entered the country and bombed the Greenpeace protest vessel Rainbow Warrior in Auckland harbour, sinking it and killing a crew member. Explaining the intent of the mission 30 years afterwards, Colonel Jean Luc Kister, the leader of the team that placed the bombs on the vessel's hull, claimed that the aim was to sink it in shallow water and "not injure anyone". ${ }^{21}$ The action was undertaken to prevent the vessel leaving New Zealand to protest at the Mururoa Atoll nuclear testing site. New Zealand, still without any terrorist legislation in 1985, charged the two agents captured afterwards with manslaughter. They were never charged with conspiracy to sink the vessel, nor for the act of doing so. They served one year in a New Zealand prison, before being removed to French territory to serve a much reduced term.

Two years later in May 1987, following the military coup in Fiji, Air New Zealand Flight 24 was hijacked by a man carrying explosives at Nadi airport. New Zealand Special Air Service personnel left en route to Fiji, but before they arrived the flight crew overpowered the hijacker, hitting him across the head with a whisky bottle. He was charged with illegal possession of explosives in Fiji. He later became a New Zealand citizen and reportedly has since travelled regularly on Air New Zealand flights to Fiji. ${ }^{22}$

New Zealand's terrorism tended into recession in the 1990s as the domestic and international stimuli for violence in previous decades subsided. With the end of the Cold War, French nuclear testing and collapse of apartheid in South Africa, the violence related to all of these issues vanished as a result. New Zealand based individuals and groups were periodically discovered by intelligence or police investigators sending funds, and at times materiel, to terrorist groups overseas. These investigations stopped short of prosecution, before and after $9 / 11$, as the culprits were not seen as threatening New Zealand national security. ${ }^{23}$

Simmering away throughout the entire period however had been a rising challenge to traditional interpretations of the Treaty of Waitangi and its application to contemporary issues regarding Maori Land. The creation of the Waitangi Tribunal in 1975 to 
consider the application of (then undefined) principles of the Treaty did not alleviate growing contention over Maori Land rights. Contention over Treaty issues was generally peaceful, with occasional skirmishes consistent with protests and policing them. Some publicity was given in the late 1970s to Maori activists thought to have visited Cuba for insurgency training and for some time there was official concern that New Zealand's ethnic gangs could become politicised. ${ }^{24}$

In 2000 there was considerable controversy over the activist Tame Iti and others flying to Fiji to support the second military coup there, although they were prevented by Fijian authorities from entering the country. ${ }^{25}$ Their return was delayed by a bomb threat against the Air New Zealand flight they were on, although the origin of the threat was unclear. Race relations undulated in New Zealand during the last decade of the 20th century and first decade of the 21st, but no existential threat emerged from this quarter until 2007 when a police surveillance operation that had been running in the Urewera area for two years was terminated. This is discussed below.

Emerging during the 1990s, and showing itself intermittently into the new millennium were signs of Right-Wing Extremism. Possibly emerging in response to increased Maori activism and increasing immigration, was a 'skinhead' presence with nationalist or supremacist views, feeding a variety of generally small white power criminal gangs. There were some racially motivated wilful damage and arson incidents against Jewish, Muslim, Maori and other buildings from time to time, as well as assaults and occasional homicides - often years apart. The kernel of terrorism, or politically/racially motivated violence could have been read into some of these incidents, but the Right-Wing 'movement' remained small, fractious and unconvincing. Nevertheless, Right-Wing individuals and groups remained periodically monitored by police and NZSIS in the late 20th and early 21 st centuries. ${ }^{26}$

Of the Right-Wing groups that have emerged in New Zealand the most notable was the National Front which held 'Flag Day' rallies that never attracted more than 100 people. The Flag Day marches were held once a year (unless they were cancelled), and were often met by larger Left-Wing groups. They also brought Right-Wing members to Police attention, but investigation found little evidence of serious concern. National Front members were sometimes 'beaten up' or intimidated by individuals offended by their views. ${ }^{27}$

In 2005 two men with Right-Wing connections were jailed after vandalising Auckland mosques in the wake of the London terror attacks. They caused an estimated $\$ 14,000$ of damage and scrawled RIP London on the exterior walls of one of the mosques. In 2008 three men broke into the Government Communications Security Bureau (GCSB) SIGINT base in Blenheim causing $\$ 1$ million worth of damage to voice their opposition to the War on Terror. They were acquitted on a defence of 'acting in the public good. ${ }^{28}$ Both of these actions were cases of intentional damage. Both used the act of damaging 
property to convey a political message to domestic and international audiences. How close did they come to the threshold of terrorism? Whatever the answer, New Zealand's well embedded tradition of inconsistency in dealing with political violence was accentuated by the difference in the outcomes of the two cases and undermines recent media claims of a security sector 'blindness' to Right-Wing Extremist offending.

In the meantime other countries began experiencing the outward flow of 'foreign fighters' to join post-Cold War conflicts in Eastern Europe in the early 1990s, many inspired by the gruesome fate of Muslim minorities. As Al Qaeda emerged, small numbers from many countries gravitated to its training camps. There is no publicly available evidence to suggest that New Zealanders did so, and after the 9/11 attacks New Zealand did not experience the terrorist plots - prompted or inspired by $\mathrm{Al}$ Qaeda - that many of its traditional allies did. Unlike other international stimuli for terrorism in the past, $\mathrm{Al}$ Qaeda's message did not resonate in New Zealand.

But international events caused planned extremist action nevertheless. Writing in Jane's Intelligence Review Paul Smith alluded to one such instance in 2000 just prior to the Sydney Olympic Games:

As part of an investigation into alleged human smuggling operations, police in Auckland raided an apartment, which was later described as a 'virtual command centre' for possible terrorist attacks in nearby Australia. Police discovered detailed maps and other evidence suggesting that the group intended to attack a small nuclear facility located in Sydney. Some members of the group had apparently acquired New Zealand passports, which could then be used for easy entry into numerous countries, including Australia. Police speculated that the New Zealand passports were preferred because they tend not to arouse suspicion. ${ }^{29}$

Smith does not name who comprised the group, but French Muslim convert Willie Brigitte was arrested in 2003 for planning an attack of Sydney's Lucas Heights nuclear reactor. ${ }^{30}$ Brigitte had links to Faheem Lodhi who was convicted in 2006 for planning to attack Sydney's electricity grid. Both men possibly spent time in New Zealand to allay suspicion of their intent - not the first time that an Australian/New Zealand link has existed as forerunner to attempted terrorism in either country. New Zealand as a hiding place either before or after terrorist events elsewhere is another theme emerging from the 1970s and recurring in Christchurch in 2019 - Tarrant's manifesto claims he initially intended to lay low in New Zealand, to prepare for his attack presumably in Australia.

In the meantime, home-grown threats continued to emerge intermittently in New Zealand. A series of cyanide-laced letters were sent containing threats to attack US golfer Tiger Woods during his 2002 visit to New Zealand, prompting a significant increase to the security around him. ${ }^{31}$ The following year letters were sent to US, British and 
Australian diplomatic missions threatening an attack on public utilities during the Americas Cup regatta in Auckland..$^{32}$ In 2006 a Saudi national on a Yemeni passport, Rayed Mohammed Abdullah Ali was arrested in Palmerston North, having been identified as previously associated with the $9 / 11$ attackers while living in the US. Ali had been undertaking flying training at the Manawatu Aero Club, which almost certainly contributed to the decision to quickly deport him..$^{33}$ Two years later a Muslim woman from New Zealand arrived in Yemen to become the third wife of Anwar al Awlaki, who had by this time, become a fervent on-line radicaliser connected to multiple terrorist plots. ${ }^{34}$ Awlaki was killed in a drone strike in 2011.

In February 2008 a Somali refugee boarded a regional flight from Blenheim to Christchurch; after the flight had taken off she threatened the pilots with a knife also claiming to have a bomb on board. In the course of the flight she stated that she wanted to fly to Australia, or crash into the sea and told passengers they were going to die. While the flight was not diverted, she remained armed and threatening until it landed when she was eventually overpowered by the crew. While there was no political motive, and mental health was clearly a factor, her actions exposed the risk associated with the lack of any security screening on regional flights to small locations within New Zealand. ${ }^{35}$ In 2019 these regional flights are still without passenger security screening, and the potential for them to be used to move drugs or other illicit contraband, or to be targeted by terrorist actors, appears not to be realised.

In the immediate post-9/11 period, New Zealand finally enacted terrorist-specific legislation with the Suppression of Terrorism Act 2002. This development was to ensure compliance with United Nations Security Council resolutions in the wake of the 9/11 attacks, and not a response to any domestic circumstance in New Zealand. The reluctance with which this was done is evident in the Act's convoluted definition of terrorism, its poor conception and practical impotence.

In 2007 a two year investigation resulted in several search warrants citing the Suppression of Terrorism Act, being executed against activists using the Urewera Forest to train with firearms and Molotov cocktails. The activists were associated with various causes, although appear to have been led by the prominent Maori activist Tame Iti - who had attempted to travel to Fiji to support the 2000 coup. The Police affidavit leaked to the media after the arrests (and then leaked again via wikileaks) highlighted recurring camps attended by individuals who 'trained' with a range of firearms, including semi-automatic weapons, many of which were acquired via TradeMe. The affidavit also cited electronic intercepts of conversations discussing the assassination of public figures and generalised references to a race war. ${ }^{36}$ However, the Solicitor General subsequently ruled out any charges under the Terrorism Suppression Act describing it as "incoherent and unworkable" and unable to be applied to the circumstances observed by police. ${ }^{37}$ 
In 2014, 60-year-old Jeremy Kerr threatened to contaminate baby formula using letters sent to Federated Farmers which contained the formula laced with 1080 poison. The toxin is routinely used as a pest control measure on government land, including land administered by the Department of Conservation (DOC) and its use continues to be controversial. Kerr demanded an end to the use of the toxin in New Zealand, or he would lace formula destined for sale in New Zealand and overseas. He was eventually identified and arrested, having not carried through with his threat - although it was estimated his actions had cost the country $\$ 37$ million. ${ }^{38}$ Once again, the Suppression of Terrorism Act was not used, and charges of criminal blackmail were laid instead. Kerr had competing personal financial motives, but the 1080 debate continues to evoke threats of violence against DOC staff, vehicles and facilities. In 2017 threats were made by anti-1080 activists to bring down helicopters used by DOC and threats to kill staff and sabotage equipment continued to be made intermittently by anti-1080 activists throughout $2018 .^{39}$

The emergence of the cyber environment as a display space for ISIS propaganda from 2013 onwards prompted security sector concern about New Zealanders engaging with that propaganda, either wanting to go to Iraq and Syria to join jihadist movements there, or remaining in New Zealand and being motivated to act locally. A few New Zealanders joined the ranks of the foreign fighters before legislation was implemented to prevent them doing so. Daryl Jones - Muslim bin John - a dual Australian New Zealand citizen was killed in a drone strike in Yemen in November 2013. ${ }^{40}$ Mark John Taylor, who knew Jones, left for Syria in 2014 and, a year later, posted a YouTube video calling on supporters to stab police or soldiers in New Zealand on ANZAC day. ${ }^{41}$

Those of concern to NZSIS in New Zealand had hovered around 30-40 individuals prior to March 2016 - they remain anonymous except for the few who have crossed the threshold to offend criminally. ${ }^{42}$ In 2016 two men appeared before New Zealand Courts, one for distributing violent propaganda, while the other walked into the US Consulate in Auckland and asked if the building was bombproof, repeatedly shouting "ISIS is here" when he was subsequently arrested. ${ }^{43}$ A youth was arrested in Christchurch in 2017 for actions inspired by on-line content, which were suppressed by the Court at his sentencing. ${ }^{44}$ In April 2018 a Dannevirke man was sentenced for possession of ISIS symbols and images, videos of graphic violence, a terrorist handbook as well as sexual images of children. ${ }^{45}$ All of these individuals have been prosecuted for offences under existing criminal legislation. ${ }^{46}$ Mark Taylor remains alive and in a Kurdish prison camp. His return to New Zealand seems unlikely, and if he did return - it is not clear whether he would face the judiciary. The Suppression of Terrorism Act could not be applied in New Zealand in 2007, it is difficult indeed, to see how it could be used against a New Zealander who was with a terrorist organisation on the other side of the globe today. 
In 2019 an Australian male who had initially arrived two years previously to lay low in New Zealand, and prepare himself for a Right-Wing inspired attack - presumably in Australia, decided instead to exploit New Zealand's vulnerable firearms regime to legally acquire an arsenal of semi-automatic weapons. Harnessing social media platforms to publicise his action globally, he went on a shooting spree that resonated around the world in a manner that no other New Zealand event ever had. Media reports in New Zealand and around the world gave variations of "The end of innocence" reporting that New Zealand was not immune to terrorism after all, and that New Zealand's isolation which had protected it until now, would do so no longer.

Had New Zealanders paid greater heed to terrorism in their own past, they would have already known that their isolation had not insulated their country from terrorism for fifty years, and the innocence supposed to have been lost now - was lost a long time ago. Despite several evident terrorist or terror-related acts, no one prior to Tarrant has ever been charged with a terrorist offence in New Zealand. In many cases Left-Wing terrorism has been explained away by the nobility of the cause - opposition to the Vietnam War, nuclear testing in the Pacific or Apartheid in South Africa. Due to the ultimate success of such causes, the coinciding terrorism has simply merged into the greater narrative of noble protest. Contrary to the emerging media myth that New Zealand has gone easy on its Right-Wing activism, it has been generally true that historically there has been more Left-Wing political violence in New Zealand. Where Right-Wing actors have committed offences and been caught, they have been prosecuted and convicted.

New Zealand has had two distinct periods of sequential terrorism, both amid periods of significant civil protest, where bombings, hoaxes and threats have occurred in a connected succession. New Zealand has faced organised international terrorism at least twice before, with the Ananda Marga plot in 1975 and the attack on the Rainbow Warrior a decade later. New Zealand has been vulnerable to international influences encouraging domestic terrorism, and on a number of occasions a trans-Tasman link has been evident in terrorism incidents in New Zealand and Australia.

New Zealand's most prominent terrorist theme is of autonomous actors, on the fringes of groups - or entirely detached from them, often with mixed motives, acting largely alone. Most of the log of events outlined above have been 'missed' by security agencies, and occurred entirely 'out of the blue'. A number of these incidents were almost certainly undetectable. Expanding watch-lists seems to be the automatic reaction by states around the globe to a terrorist event - a problematic approach when dealing with autonomous actors and akin to searching for ghosts. In the wake of Christchurch, doing more of what did not detect Brenton Tarrant, will not increase the likelihood of detecting anyone like him in the future.

Where individuals have been caught in possession of material or involved in activity deemed likely to lead them to violence, there is no way of knowing if a more sinister 
outcome would have resulted had no action been taken. In 2007 Operation Eight appeared to have completely disrupted a suspect series of actions, but the curse of prevention haunts this operation. It will never be known if anything would have come of it had police not acted and the police for their troubles attracted massive media and public criticism. Instead of taking stock of what was actually occurring by those under surveillance, and addressing the gaps in the legislative architecture that was supposed to protect New Zealand from terrorism, public commentary focused on racism and police tactics. If the Arms Act had been amended to ban semi-automatic weapons in 2007, Brenton Tarrant would not have been able to access them so readily in 2019 .

History appears to be repeating itself in the wake of the Christchurch attack, public commentary has once again zeroed in on racism, and what the security sector missed, satiating New Zealand's bizarre desire to flagellate itself over its failures as panacea for them. The fundamental and long-standing omissions in New Zealand's terrorism legislation and lack of a comprehensive counter terrorism strategy have been deliberately left out of the purview of the Royal Commission appointed to investigate the Christchurch Mosque attacks. The Royal Commission will sap already stretched police and intelligence resources in its attempt to find if the security sector missed something. Resources would be better put toward addressing the omissions in legislation, reviewing security sector resource allocations, analysing the risks of cyberspace and in enhancing public understanding of what 'security' means in an age of individualistic terrorism.

There has yet to be devised a security system that can guarantee the detection or prevention of autonomous actor attacks, and deciding after the event that some unrecognised action at the time could have been done to avoid the Christchurch attack will not prevent the next one. New Zealand would be in a better position to mitigate the risk of future terrorism, if it owned up to its terrorism history and critically noted and analysed the trends that have emerged over time in its terrorism experience as an indicator of what may emerge tomorrow. Brenton Tarrant seemingly emerged 'out of the blue' like so many others - in a country that has refused to acknowledge that it has a lengthy history of autonomous actors, mostly unconnected to each other, thoroughly exploiting our complacency, and committing unexpected acts of violence against us. Each time it occurs we exhibit the same complete surprise as if it had never happened before.

\footnotetext{
1 B.K.Greener-Barcham, "Before September: A History of Counter-Terrorism in New Zealand," Australian Journal of Political Science, 37(3) (2002), p.511.

2 Bruce Hoffman, Inside Terrorism, (New York, Columbia University Press, 2006), pp.18-19.

3 Tim Shadbolt, Bullshit \& Jellybeans, Wellington, Alister Taylor, 1971), pp.127-130.

4 Untitled Post, 13 December 2005. Available at http://rnzaf.proboards.com/thread/1261?page=2, (accessed 15 October 2018).
} 
5 "How the hippies really did help change the world," New Zealand Herald, 12 February 2011. Available at https://www.nzherald.co.nz/lifestyle/news/article.cfm?c_id=6\&objectid=10705881, (accessed 15 October 2018).

6 Shadbolt, pp.127-130.

7 Kathleen Belew, Bring the War Home: The White Power Movement and Paramilitary America (Cambridge \& London, Harvard University Press, 2018), p.10.

8 "Guards join jets to prevent nuclear protest skyjack," The Dominion, 28 June 1972, National Library of New Zealand (NLNZ).

9 "Arsons, marches and petitions: the abortion debate in 1970s New Zealand," 13 November 2015. Available at http://heritageetal.blogspot.co.nz/2015/11/arsons-marches-and-petitions-1970s.html, (accessed 10 May 2018).

10 "Mystery hole revealed sinister plot," New Zealand Herald, 30 June 2000. Available at https://www. nzherald.co.nz/nz/news/article.cfm?c_id=1\&objectid=138379, (accessed 10 May 2018).

11 John Battersby, "Can Old Lessons Inform Current Directions: Australia, New Zealand, and Ananda Marga's Trans-Tasman “Terrorism” 1975-1978, Studies in Conflict and Terrorism (2019), available at DOI: $10.1080 / 1057610 X .2019 .1575031$

12 Ibid.

13 Ananda Marga in New Zealand, 9 August 1979, NZSIS 26/6/17, folio 965, OIA release to the author 3 May 2018.

14 Email (Sender and Recipient withheld), 2 April 2019, former police officer recollections of Ananda Marga, forwarded to the author.

15 Rachel Landers, Who bombed the Hilton? (Sydney, NewSouth, 2016) p.126.

16 "Death Blast Linked to Bomb Plot," New Zealand Herald, 15 May 1976, NLNZ.

17 The details referred to in this paragraph are drawn from a NZ Police list of incidents, attached as Annex W to "Operation Rugby, 19 July-13 September 1981," Police Headquarters Wellington, February 1982, NZ Police Library. The reference to realistic bomb hoaxes was located in "Anti-Springbok Tour Protests," Appendix to 3524, 21 August 1981, NZSIS, Declassified 4 November 2011.

18 "The Snowman and the Queen: The story of a Kiwi teen terrorist and would-be assassin," Stuff.co.nz, 8 January 2018. Available at https://www.stuff.co.nz/national/crime/99760154/the-snowman-and-thequeen-the-story-of-a-kiwi-teen-terrorist-and-wouldbe-assassin, (accessed 11 June 2018). The NZSIS documents this series was based on have since been released to the author under OIA request.

19 "An anarchist with a death wish," 23 November 2015, Radio New Zealand, (accessed 17 May 2019). Available at https:/www.rnz.co.nz/news/the-wireless/373579/an-anarchist-with-a-death-wish

20 "Trades Hall bombing evidence points to a key suspect, retired marine engineer Edgar Kidman," Stuff.co.nz, 16 July 2019. Available at https://www.stuff.co.nz/national/crime/114098187/trades-hallbombing-evidence-points-to-a-key-suspect-retired-marine-engineer-edgar-kidman (Accessed 16 July 2019).

21 "Exclusive: Rainbow Warrior bomber breaks his silence after 30 years," 6 September 2015, 1NewsNow. Available at https://www.tvnz.co.nz/one-news/new-zealand/exclusive-rainbow-warriorbomber-breaks-his-silence-after-30-years-q09219 (accessed 17 May 2019).

22 “Air New Zealand highjacker now flies with them," The Dominion Post, 17 May 2014. Available at http://www.stuff.co.nz/national/10054582/Air-NZ-hijacker-now-flies-with-them (accessed 21 February 2018).

23 Personal Communication, Police Officer (name withheld) to Author, 8 July 2019.

24 "Government eye on Maori going to Cuba," The Dominion, 17 October 1979, 38/9/6/2, NLNZ. 25 "Iti activists 'went to support the Fijian,"” New Zealand Herald, 3 July 2000. Available at https:// www.nzherald.co.nz/nz/news/article.cfm?c_id=1\&objectid=142787 (accessed 1 June 2018).

26 Personal Communication, former Intelligence Officer (name withheld) to Author, 3 July 2019.

27 Interview transcript, former Police Officer, name withheld, 6 May 2019.

28 “Waihopai Damages Action Dropped," Stuff.co.nz, 5 February 2014. Available at http://www.stuff. co.nz/national/9688895/Waihopai-damages-action-dropped (accessed 4 July 2019).

29 Paul J Smith, “The Terrorists and Crime Bosses," Jane's Intelligence Review, 1 July 2001. Available at https://www.globalpolicy.org/component/content/article/173/30381.html (accessed 31 May 2018). 
30 'Terror accused Brigitte moved to Australia 'for new life', New Zealand Herald, 8 February 2007. Available at https://www.nzherald.co.nz/world/news/article.cfm?c_id=2\&objectid=10423022 (accessed 1 June 2018).

31 "Tiger Woods, the NZ Golf Open and the terrorist cyanide threat," Stuff.co.nz, 30 March 2018. Available at https://www.stuff.co.nz/national/102697753/tiger-woods-the-nz-golf-open-and-the-terroristcyanide-threat (accessed 11 June 2018).

32 "Revealed: Threat to Tiger Woods in NZ in 2001," New Zealand Herald, 12 March 2015. Available at http://www.nzherald.co.nz/nz/news/article.cfm?c id=1\&objectid=11415784, (accessed 21 February 2018); "Cyanide Threat to New Zealand Open," Independent, 7 January 2002. Available at http://www. independent.co.uk/sport/golf/cyanide-threat-to-new-zealand-open-9215694.html (accessed 7 January 2002).

33 "Pilot with 9/11 links found in NZ," New Zealand Herald, 10 June 2006. Available at https://www. nzherald.co.nz/nz/news/article.cfm?c_id=1\&objectid=10385963 (accessed 30 May 2018).

34 Scott Shane, Objective Troy: A Terrorist, a President and the rise of the Drone (New York, Tim Duggan Books, 2015), p.163. The woman did not remain long, leaving him after only four months.

35 "I should have killed the pilot' - hijacker," The Press, 31 January 2009. Available at http://www.stuff. co.nz/the-press/742804/I-should-have-killed-the-pilot-hijacker (accessed 3 February 2018).

36 "The Terrorism Files," The Dominion Post; 14 November 2007; "Watched at every step," The Dominion Post, 14 November 2007, NLNZ. These items were accessed using microfilm hardcopies the online versions have been taken down by The Dominion Post following prosecution for publishing legally privileged material that was leaked after the Solicitor General's decision not to charge anyone under the Suppression of Terrorism Act 2002.

37 "Review of terror laws stopped," Sunday Star Times, 15 September 2013. Available at http://www. stuff.co.nz/national/9166763/Review-of-terror-laws-stopped, (accessed 27 February 2018).

38 "Threat to contaminate infant formula with 1080: Arrest made," New Zealand Herald, 13 October 2015. Available at https://www.nzherald.co.nz/business/news/article.cfm?c_id=3\&objectid=11528344, (accessed 11 June 2018); see also John Battersby, "Facing up! The legal and definitional challenges of New Zealand's approach to terrorism", New Zealand National Security: Challenges, Trends and Issues, eds. Wil Hoverd, Nick Nelson \& Carl Bradley, (Auckland, Massey University Press, 2017), pp.261-262. 39 "1080 protesters threaten to 'bring down' DoC helicopters," Newshub, 5 December 2017. Available at https://www.newshub.co.nz/home/new-zealand/2017/12/1080-protesters-threaten-to-bring-down-doc-helicopters.html (accessed 11 June 2018).

40 "Muslim bin John made bid to recruit Sydney Man," The Australian, 18 July 2014. Available at https:/www.theaustralian.com.au/national-affairs/muslim-bin-john-made-bid-to-recruit-sydney-man/ news-story/8c851 f081b046e802b0b8d55067e51f9 (accessed 7 June 2018).

41 "Self-radicalised' Kiwi most likely cause for NZ terror threat alert, intelligence expert says," Stuff. co.nz, 3 November 2016. Available at https://www.stuff.co.nz/national/politics/86059036/Self-radicalised-Kiwi-most-likely-cause-for-NZ-terror-threat-alert-intelligence-expert-says (accessed 28 February 2018).

42 "A little less danger? Deadly threats to New Zealand fall," New Zealand Herald, 7 December 2017. Available at https://www.nzherald.co.nz/nz/news/article.cfm?c_id=1\&objectid=11955317 (accessed 11 June 2018).

43 "Man shouted 'Isis is here' in scuffle was officers," New Zealand Herald, 23 June 2016. Available at http://www.nzherald.co.nz/nz/news/article.cfm?c_id=1\&objectid=11662149 (accessed 28 February 2018).

44 "Kiwi teenager radicalised online planned mass killing in Christchurch 'for Allah'", Stuff.co.nz, 16 February 2018. Available at https://www.stuff.co.nz/national/crime/101480988/kiwi-teenager-radicalised-online-planned-mass-killing-in-christchurch-for-allah (accessed 28 February 2018).

45 "Dannevirke man sentenced for Isis propaganda, child sex abuse images," New Zealand Herald, 23 April 2018. Available at https://www.nzherald.co.nz/nz/news/article.cfm?c_id=1\&objectid=12037850 (accessed 7 June 2018).

46 "Call for care in handling case of men facing first home-grown radicalisation charges," Stuff.co.nz, 6 May 2016. Available at https://www.stuff.co.nz/auckland/79703706/call-for-care-in-handling-case-ofmen-facing-first-home-grown-radicalisation-charges (accessed 28 February 2018). 